DOI https://doi.org/10.30525/978-9934-588-79-2-2.4

\title{
SIMULATION OF THE SENSOR NETWORK OF BASE STATIONS IN A LOCAL POSITIONING SYSTEM IN INTELLIGENT INDUSTRIES
}

\author{
Mospan D. V. \\ Candidate of Technical Sciences, \\ Associate Professor at the Department of Electronic Devices \\ Kremenchug Mykhailo Ostrohradskyi National University \\ Mospan V. O. \\ Candidate of Technical Sciences, \\ Associate Professor at the Department of Electronic Devices, \\ Dean of the Faculty of Electronics and Computer Engineering \\ Kremenchuk Mykhailo Ostrohradskyi National University \\ Fomovskaya O. V. \\ Candidate of Technical Sciences, \\ Head of the Department of Electronic Devices \\ Kremenchuk Mykhailo Ostrohradskyi National University \\ Kremenchuk, Poltava region, Ukraine
}

Communication between equipment, sensors, mobile robots and even products produced in the industry within the concept of Industry 4.0 is at the forefront. In the intelligent production of equipment, controllers and sensors interact with each other and directly with Ethernet or in the cloud [1].

Decentralization in production management in the ideology of Industry 4.0 allows to process data directly into sensors. The sensors process the collected data to transmit information, which is then processed in Ethernet or in a cloud service for the next process.

Cloud service is becoming more important for process management. The main computing power is moved to the periphery. This makes production more flexible and dynamic, which can respond to changes individually and quickly at any time.

In intelligent manufacturing, the work of moving parts between equipment is performed by an intelligent vehicle. This equipment always communicates with the cloud and loads from it the manufacturing technology of a particular part. The manufacturing technology (processing) of the part is always stored in the cloud and is available by a unique part identifier. At 
each particular point in time, information about the current operation and its characteristics is available.

We will consider the components of an automated system as agents of a distributed process control system [2].

For each technological operation, a search for suitable and currently free equipment (agent) is performed. If available equipment is not available, then the part is moved to temporary storage. Information about such a detail is posted in the cloud. Subsequently, any mobile intelligent platform can pick up this part for further processing.

After moving the part to the machine, along with it the data necessary for the implementation of the current technological operation is transmitted to it. Information is downloaded to the internal memory of the machine from the cloud by the identification number that the smart mobile device reports.

Thus, an important and urgent task is to ensure reliable uninterrupted communication between distributed mobile agents with a sufficiently high speed of messaging.

To solve this problem, it is proposed to use a network of base stations covering the area of the production workshop. Base stations act as reference marks for the local navigation system of mobile robots, as well as for the exchange of information between autonomous independent agents, which can be various sensors. Using the technology of interaction between nodes, we get a scalable and reliable network of base stations. To ensure the speed of message delivery, it is proposed to use a multi-path algorithm to find the route for message delivery between base stations.

Wireless sensor networks are actively developing automation and control, monitoring and control systems. Interacting with control devices, the sensors create a distributed, self-organizing system for collecting, processing and transmitting information. The concept of «self-organizing network» is defined as a system in which devices are able to find each other and form a network, and in the event of a failure of any node, new routes can be established for message transmission.

Currently, wireless sensor networks are increasingly used in industrial automation systems for monitoring, control, and local positioning of mobile robots $[1,2]$. Their main advantage is a flexible architecture and minimal costs for their installation and operation. An important feature of wireless sensor networks is their self-organization. Each separately located node is grouped with the same node located in the range of the antenna and, thus, a network for data transmission is formed. Integrated in the wireless sensor 
network sensors form a geographically distributed self-organizing system for collecting, processing and transmitting information [2].

The use of sensor networks in solving problems associated with the local positioning of mobile objects due to their great flexibility, reliability and scalability. Sensor networks can quickly adapt to changes in the environment due to the possibility of self-organization. The scalability properties make it possible to quickly deploy a local positioning system on the ground. Another important factor in choosing a sensor network for organizing data exchange in a local positioning system is general principles of work organization.

The local positioning system based on the DWM1000 modules [1, 2] uses for its operation base stations located at a uniform distance from each other over the area of movement of mobile objects. In local positioning systems, where the principle of determining the distance from the tag to the nearest base stations [3] is used, it is also advisable to use a selfconfiguring network.

Base stations are used to determine the distance between stations and a moving object that is within range of the base station. The mobile unit is located at the intersection of the circles based on data about the distance. The principle of operation of the local positioning system is described in [3].

Just like sensor networks, base stations organize a cellular structure that covers a specific area. Considering compatible range, about $100 \mathrm{~m}$, the sharing of the DWM1000 modules and the RF transceiver, as a sensor network node becomes obvious $[4,5]$.

Figure 1 shows a block diagram of a combined base station using the DWM1000 and RFM69HW modules. The Atmega328 device is used as the master and slave controllers. The Atmega328 device is used as the master and slave controllers. The sensor network node is made on the module RFM69HW. Using the SPI interface, this module communicates with the main controller.

The functions of the main controller are: the exchange of information with other nodes of the sensor network, participation in building the route of data transmission and network reconfiguration.

Receiving commands from the main base station, this controller makes requests to search for a mobile device and determine the distance to it. To do this, use the module DWM1000. This module is connected to the slave controller also via the SPI interface. When a request is received from the master controller, the procedure initiating the determination of the distance to the moving object is performed. 
To determine the local coordinate space used in the data received from the base stations. Once the mobile unit enters the range of action station, distance measurement is performed up to the mark and is defined current signal level. If the signal level is less than the threshold value, then this station does not participate in determining the coordinates. The rest of the base stations transmit the collected readings to the main coordinate determination module [6].

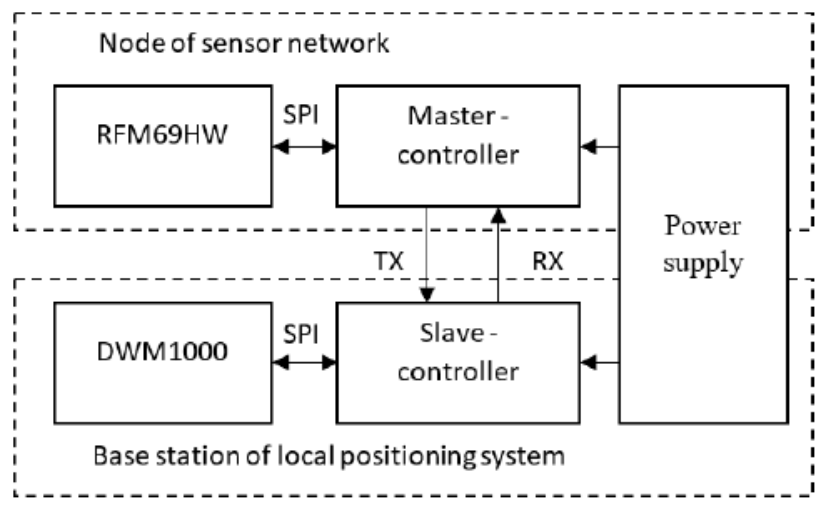

Fig. 1. Base station block diagram

RFM69HW has the ability to work on 16 independent channels and use addressing within the network. Thus, it is possible to build independent wireless networks or even separate segments to implement new positioning algorithms.

An example of the use of the proposed architecture of the local positioning system is shown in Figure 2. Base stations are installed around the perimeter of a certain area based on the DWM1000 and RFM69HW modules. The mobile robot moves along a given trajectory. Information about the position of the robot in space is taken on the basis of data on the distance from each base station to the DWM1000 module located on the mobile robot.

As you can see from Figure 2, the tag with the DWM1000 module is attached to the moving object. Moving from one coverage area to another, between base stations, the tag participates in data exchange to determine its distances to each base station within the range of the module. The number of base stations in the range of the tag improves positioning accuracy. Therefore, it is necessary, if possible, to increase the distribution density of the towers along the route of the mobile robot. 


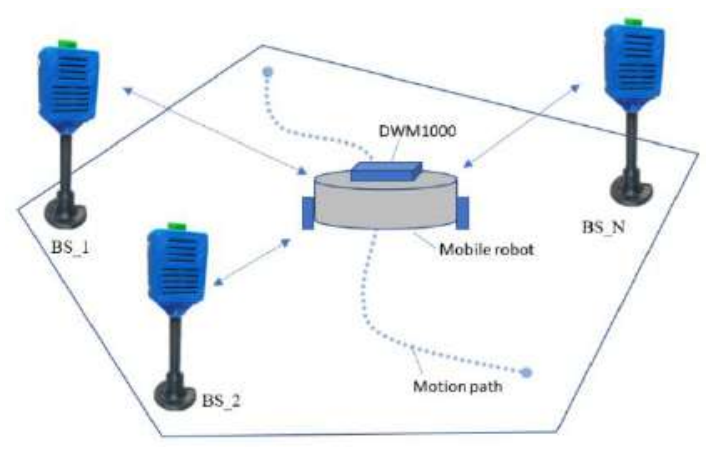

Fig. 2. Architecture of the local positioning system

In the simulation, the initial and final nodes are selected. After the simulation starts, all possible signal propagation paths between nodes are checked.

Thus, to transfer information between base stations, it is proposed to use the technology of interaction between nodes used in wireless sensor networks. Thus, we get a scalable and reliable network of base stations.

The simulation results showed that the higher the density of network nodes per square of the room space, the more reliable the network, however, as the density of nodes increases, the time to build a signal propagation route increase. Therefore, it is necessary to use additional filtering algorithms for preliminary selection of optimal paths.

\section{References:}

1. Nevliudov I. S., Novoselov S. P., Sichova O.V. Programming technology of industrial controllers in an integrated CODESYS environment: Study manual. Kharkiv: KNURE, 2019. 264 p. DOI: 10.30837/978-966659-265-4.

2. Novoselov, S., Donskov, O. Distributed local positioning system using DWM1000 location chip. 4th International Scientific-Practical Conference Problems of Infocommunications. 2017. P. 489-492. DOI: 10.1109/INFOCOMMST.2017.8246445.

3. Novoselov S., Sychova O., Tesliuk S. Development of the method local navigation of mobile robot a based on the tags with QR code and wireless sensor network. IEEE XVth International Conference on the Perspective Technologies and Methods in MEMS Design (MEMSTECH). 2019 P. 46-51. DOI: 10.1109/MEMSTECH.2019.8817405. 
4. Nevlydov I., Filipenko O., Volkova M., Ponomaryova G. MEMS-based inertial sensor signals and machine learning methods for classifying robot motion. IEEE Second International Conference on Data Stream Mining \& Processing (DSMP). 2018. P. 13-16. DOI: 10.1109/DSMP.2018.8478613.

5. Xuxun Liu. Routing protocols based on ant colony optimization in wireless sensor networks: a survey. IEEE Access. 2017. Vol. 5. P. 2630326317. DOI: 10.1109/ACCESS.2017.2769663.

6. Mospan V., Fomovskaya O., Mospan D. et al. Possibility of the optimal control method application in energy-consuming technological processes of RED production. IEEE International Conference on Modern Electrical and Energy Systems (MEES). 2019. P. 286-289, DOI: 10.1109/MEES.2019.8896363.

DOI https://doi.org/10.30525/978-9934-588-79-2-2.5

\title{
РОЗРОБКА МОДЕЛІ ВИБОРУ ПРОМИСЛОВОГО РОБОТА
}

\author{
Петренко Ю. А.
}

доктор технічних наук, професор, професор кафедри автоматизаиіі та комп 'ютерно-інтегрованих технологій

Харківського наиіонального автомобільно-дорожнього університету

Посукан Р. В.

студент кафедри автоматизачії

та комп 'ютерно-інтегрованих технологій

Харківського національного автомобільно-дорожнього університету м. Харків, Україна

У всьому світі спостерігається підвищення рівня роботизації в промисловості, в соціально-економічному розвитку та приватному секторі життя.

Однак економіка України і взагалі уся глобальна економіка страждають від спаду продуктивності праці. Зокрема, зазначається, що глобальне зростання продуктивності праці, вимірюваний як середня зміна ВВП на одного зайнятого, в останні роки сповільнився. Якщо в період з 1999 по 2006 рік зростання становило $2.6 \%$ в рік, то в період 3 2007 по 2012 роки він виріс на 2.5\%, а потім і зовсім почав знижува- 